\title{
PENGARUH BIAYA OPERASIONAL TERHADAP LABA PERUSAHAAN MEDIA GROUP ELECTRONIC AND CELLULER MALANGBONG
}

\author{
Neneng Achriani', Ahyo Ruhyanto ${ }^{2}$, Rini Agustin Eka Yanti ${ }^{3}$ \\ 1,2,3 Program Studi Pendidikan Akuntansi, Universitas Galuh JL.R.E Martadinata No. 150, Ciamis, Indonesia \\ Email: nenengachriani99@gmail.com, riniagustin.eka@gmail.com
}

\begin{abstract}
ABSTRACK
The problem that often occurs in companies is regarding the amount of costs incurred to fulfill the company's operational activities that are not accompanied by an increase in profits generated by the company. If in the company there is a decrease or increase in operating costs, then the company has problems in achieving maximum profit, resulting in a decrease in company profits. The research method used is descriptive with a quantitative approach. Statistical analysis used is Pearson correlation coefficient, coefficient of determination analysis, and hypothesis testing. Based on the calculation of the coefficient of determination, it can be concluded that the effect of operating costs on company profits is $0.0000000196 \%$, while the remaining $99.99 \%$ is influenced by other factors not examined by the author. Based on the calculation of the hypothesis test using the $t$ test, the resulting $t$ value $=-0.00242$ decision rule $d k=(n-2)=(5-2)=3$ at level $=0.05$ (which is commonly used) with $n=5$ then $t$ table is 3.182, thus the value of $t$ count is smaller than $t$ table, so Ho is accepted and Ha is rejected. So from the calculations above, the proposed hypothesis is rejected, namely operating costs have no significant effect on company profits. The results show that operational costs have a very low and negative relationship. Operational costs have no significant effect on profit.
\end{abstract}

Keywords: Operating Costs, Profit

\begin{abstract}
ABSTRAK
Permasalahan yang sering terjadi pada perusahaan adalah mengenai besarnya biaya yang dikeluarkan untuk memenuhi aktivitas operasional perusahaan yang tidak disertai dengan kenaikan laba yang dihasilkan perusahaan. Jika dalam perusahaan terjadi penurunan atau kenaikan biaya operasional, maka perusahaan mengalami kendala dalam pencapaian laba yang maksimal sehingga berakibat pada penurunan laba perusahaan. Metode penelitian yang digunakan adalah deskriptif dengan pendekatan kuantitatif. Analisis statistik yang digunakan adalah koefisien kolerasi pearson, analisis koefisien determinasi, dan pengujian hipotesis. Berdasarkan perhitungan koefisien determinasi dapat disimpulkan bahwa pengaruh biaya operasional terhadap laba perusahaan adalah sebesar 0, 0000000196 \%, sedangkan sisanya sebesar 99,99 $\%$ dipengaruhi oleh faktor lain yang tidak diteliti penulis. Berdasarkan perhitungan uji hipotesis dengan menggunakan uji $t$ dihasilkan nilai $t_{\text {hitung }}=-0,00242$ aturan keputusan $d k=(n-2)=(5-2)=3$ pada taraf $\alpha=0,05$ (yang umum digunakan ) dengan $\mathrm{n}=5$ maka $t$ table adalah 3,182 dengan demikian maka harga $t$ hitung lebih kecil dari $t$ tabel, sehingga $\mathrm{Ho}$ diterima dan $\mathrm{Ha}$ ditolak. Jadi dari perhitungan-perhitungan diatas hipotesis yang diajukan ditolak, yaitu biaya operasional tidak berpengaruh secara signifikan terhadap laba perusahaan. Hasil penelitian menunjukkan bahwa biaya operasioanal memiliki hubungan sangat rendah dan bernilai negatif. Biaya operasional tidak berpengaruh signifikan terhadap laba.
\end{abstract}

Kata kunci : Biaya Operasional, Laba

Cara sitasi: Achriani, N. Ruhyanto, A., \& Yanti, R.A. (2020). Pengaruh Biaya Operasional Terhadap Laba Perusahaan Media Group Electronic and Celluler Malangbong. J-KIP (Jurnal Keguruan dan IImu Pendidikan), 2 (3), 171-178. 


\section{PENDAHULUAN}

Salah satu indikator keberhasilan perusahaan dapat diukur dengan kondisi keuangan dalam memperoleh laba atau sebaliknya. Laba merupakan selisih antara pendapatan dan beban-beban. Menurut Mulyadi (2013) "Laba merupakan ukuran yang seringkali dipakai untuk menilai berhasil tidaknya manajemen suatu perusahaan. Diperoleh melalui hubungan antara harga jual, volume penjualan dan biaya." Untuk memperoleh laba maka perusahaan harus memperhatikan pengendalian biaya dan pendapatan.

Menurut Subramanyam (2014) menyatakan bahwa: "Laba, dalam istilah keuangan, adalah ringkasan hasil neto dari operasi bisnis selama periode waktu tertentu". Laba merupakan perbedaan antara realisasi penghasilan yang berasal dari transaksi perusahaan pada periode tertentu dikurangi dengan biaya yang dikeluarkan untuk mendapatkan penghasilan itu. Laba adalah kenaikan modal (aktiva bersih) yang berasal dari transaksi sampingan atau transaksi yang jarang terjadi dari suatu badan usaha, dan dari semua transaksi atau kejadian lain yang mempengaruhi badan usaha selama satu periode, kecuali yang timbul dari pendapatan (revenue) atau investasi oleh pemiliknya. Dari pengertian di atas dapat disimpulkan bahwa laba adalah informasi dalam hal pencapian pendapatan diatas beban yang stabil dan meningkat dari periode yang berbeda dan mencerminkan pengembalian kepada pemegang ekuitas. Secara konseptual, laba bertujuan untuk memberikan pengukuran pada perubahan kekayaan pemegang saham (stakeholder) selama satu periode dan estimasi profitabilitas bisnis saat ini.

Sebagai data awal, penulis menyajikan laporan Laba-Rugi perusahaan Media Group Electronic and Celluler Malangbong sebagai berikut:

\begin{tabular}{ccc} 
Tabel 1. Laba Bersih Usaha PeriodeTahun & 2016-20 \\
\hline \multicolumn{4}{c}{ Tahun } & Laba Bersih Usaha (Rp) & \\
\hline 2016 & 680.400 .00 & 279,6 \\
2017 & 706.800 .000 & 277,2 \\
2018 & 663.000 .00 & 485 \\
2019 & 651.600 .000 & 384,4 \\
2020 & 691.200 .000 & 288,8 \\
Total & 3.393 .000 .000 & 3.393 \\
\hline \multicolumn{4}{c}{ (Sumber Media Group Electronic and Celluler) }
\end{tabular}

(Sumber Media Group Electronic and Celluler)

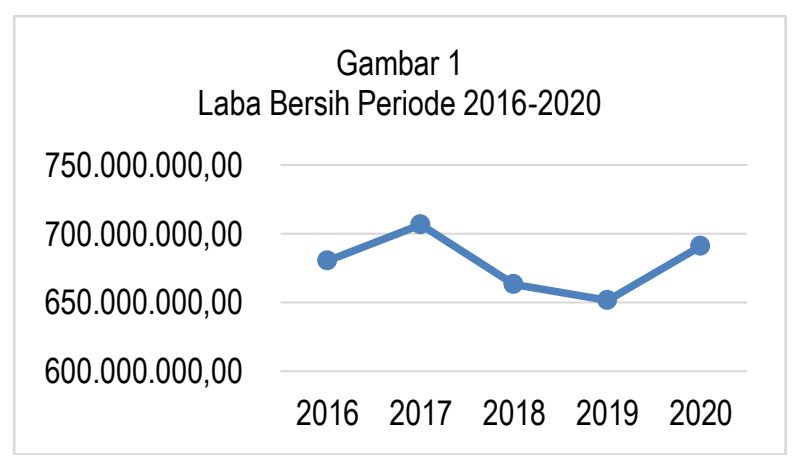

Berdasarkan tabel 1 laba yang diperoleh Media Group Electronic and Celluler Malangbong pada tahun 2016 sebesar Rp.680.400.000. Kemudian pada tahun 2017 laba yang diperoleh mengalami peningkatan sebesar 3,9 \% yaitu sebesar Rp.26.400.000 menjadi Rp.706.800.000 Kemudian pada tahun 2018 kembali mengalami penurunan menjadi $(6,2 \%)$ salah satunya karena adanya pembangunan toko baru sehingga laba yang diperoleh sebesar Rp.663.000.000. Selanjutnya pada tahun 2019 kembali mengalami penurunan sebesar $(1,7 \%)$ adanya tambahan biaya operasional yang digunakan untuk finishing toko sehingga laba yang diterima yakni sebesar Rp.11.400.000, untuk tahun 2020 laba yang diperoleh mengalami kenaikan sebesar 6,1 \% yaitu sebesar Rp. 39.600.000. 
Faktor-faktor yang mempengaruhi laba menurut Mulyadi (2013) antara lain 1) Biaya, 2) Harga Jual, 3) Volume Penjualan. Sedangkan menurut Halim, Supomo \& Kusufi (2012) faktor yang mempengaruhi laba adalah biaya dan harga jual. Dapat disimpulkan bahwa faktor-faktor yang mempengaruhi laba ada 3 yaitu Biaya, Harga jual, dan Volume penjualan. Biaya yang timbul akibat perolehan produk akan mempengaruhi harga jual, harga jual produk akan mempengaruhi bersarnya volume penjualan, sedangkan volume penjualan akan berpengaruh terhadap volume produksi dengan kenaikan volume penjualan maka konsekuensinya laba pun akan meningkat. Sehingga biaya-biaya yang dikeluarkan oleh perusahaan harus diperhitungkan secara matang.

Biaya Operasional merupakan biaya yang terkait dengan operasional perusahaan yang meliputi biaya penjualan dan administrasi umum, biaya iklan, biaya penyusutan, serta perbaikan dan pemeliharaan. Maka dari itu, biaya operasional berimplikasi langsung terhadap harga pokok jasa atau produk setiap perusahaan (Mulyadi, 2013). Biaya Operasional adalah biaya yang diperlukan untuk melaksanakan kegiatan dalam suatu proses produksi dan memiliki sifat "habis pakai" dalam kurun waktu relatif singkat, biasanya kurang dari satu tahun". Tujuan dari biaya operasional adalah untuk mengelola sumber ekonomi yang dimiliki perusahaan untuk menjalankan aktivitas dalam upaya mempertahankan dan menghasilkan pendapatan. Contoh yang termasuk biaya operasional adalah biaya obat, biaya makan, gaji pegawai, listrik, air dan sebagainya. Selanjutnya menurut Sujarweni (2017) menyatakan bahwa: "Biaya Operasional adalah biaya yang digunakan untuk mendapatkan pendapatan utama".

Biaya operasional adalah biaya yang menunjukan sejauh mana efisiensi pengelolaan usaha. Biaya penjualan dan biaya administrasi berhubungan dengan operasi yang dilakukan. Menurut Jumingan (2017) menyatakan :"Biaya usaha/Operasional timbul sehubungan dengan penjualan atau pemasaran barang atau jasa dan penyelenggaraan fungsi administrasi dan umum dari perusahaan yang bersangkutan". Berdasarkan pada empat definisi diatas dapat disimpulkan bahwa biaya operasional adalah biaya-biaya yang berhubungan langsung dengan kebutuhan perusahaan setiap harinya diluar proses produksi.

Hasil pengujian ini sesuai dengan penelitian terdahulu, hasil penelitian yang dilakukan oleh Agung Gunawan yaitu pengaruh biaya operasional perusahaan terhadap laba yang dilakukan pada tahun 2013. Berdasarkana rumusan masalah yang terdapat dalam penelitian ini, maka tujuan yang hendak dicapai adalah 1) Mengetahui gambaran biaya operasional pada Media Group Electronic and Celluler Malangbong, 2) Mengetahui gambaran laba yang dihasilkan perusahaan pada Media Group Electronic and Celluler Malangbong dan 3) Seberapa besar pengaruh biaya operasional terhadap laba pada Media Group Electronic and Celluler Malangbong.

\section{METODE PENELITIAN}

Dalam penelitian ini penulis menggunakan metode deskriptif dengan pendekatan kuantitatif, yaitu penelitian dengan data kuantitatif yang kemudian diolah dan dianalisis untuk diambil kesimpulan tentang adanya pengaruh dari biaya operasional terhadap laba perusahaan di Media Group Elektronik and Celluler Malangbong.

Sumber data sekunder diperoleh penulis menggunakan beberapa teknik yaitu: (1) Observasi (2) Dokumentasi (3) studi kepustakaan.

Dalam penelitian ini teknik analisis data yang digunakan adalah Uji Analisis Data.

Uji analisis data ini dilakukan untuk:

1. Mengetahui Jumlah Biaya Operasional di Perusahaan Media Group Electronic and Celluler Malangbong dengan melakukan observasi dan wawancara serta mengidentifikasi laporan keuangan dari perusahaan.

2. Mengetahui Jumlah Laba di Perusahaan Media Group Electronic and Celluler Malangbong dengan mengidentifikasi laporan laba-rugi perusahaan menggunakan metode full Costing 
3. Mengetahui Pengaruh Biaya Operasional Terhadap laba di Perusahaan Media Group Electronic and Celluler Malangbong, langkah - langkah yang harus dilakukan:

a. Menghitung analisis Korelasi variabel $\mathrm{X}$ dan $\mathrm{Y}$ dengan menggunakan Koefisien Korelasi Pearson

b. Menentukan nilai Koefisien determinasi

c. Menguji hipotesis penelitian dengan menggunakan uji $t$

d. Mencari nilai t tabel

e. Membandingkan nilai t hitung dengan $t$ tabel dengan kriteria dalam pengujian.

\section{HASILPENELITIAN DAN PEMBAHASAN}

\section{Hasil Penelitian}

Analisis data kuantitatif dalam penelitian ini digunakan untuk menjabarkan hasil penelitian dalam bentuk perhitungan angka yang mana diterapkan dengan menggunakan rumus-rumus statistik. Analisis data kuantitatif yang digunakan dalam penelitian ini adalah analisis Koefisien Korelasi Pearson.

Analisis Koefien Korelasi Pearson digunakan untuk mengetahui derajat atau

Kekuatan hubungan antara variabel X (Biaya Operasional) dengan variabel $Y$ (Laba Perusahaan). Berdasarkan hasil penelitian, deskripsi untuk mengukur pengaruh variabel biaya operasional $(X)$ terhadap laba perusahaan $(Y)$ diperoleh data sebagai berikut :

\section{Tabel 2. Perhitungan Analisis Korelasi Variable $X$ dan $Y$}

\begin{tabular}{cccccc}
\hline Tahun & $X$ & $Y$ & $X^{2}$ & $Y^{2}$ & $X Y$ \\
\hline 2016 & 279,6 & 680,4 & 78.176 & $462.944,2$ & 190239,8 \\
\hline 2017 & 277,2 & 706,8 & 76.840 & $499.566,2$ & 195925 \\
\hline 2018 & 485 & 663 & 235.225 & 493.569 & 321555 \\
\hline 2019 & 384,4 & 651,6 & 147.763 & $424.582,6$ & 250475 \\
\hline 2020 & 280,8 & 691,2 & 78.849 & $477.757,4$ & 194089 \\
\hline$\Sigma$ & 1.707 & 3.393 & 616.853 & 2.358 .419 & 1.152 .284 \\
\hline
\end{tabular}

Gambar 2

Perhitungan Analisis Korelasi Variable $\mathrm{X}$ dan $Y$

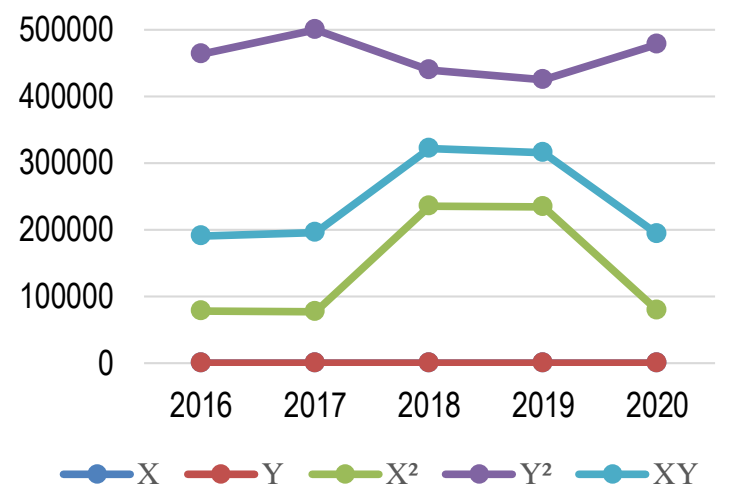

Berdasarkan perhitungan tersebut dimasukkan kedalam rumus sebagai berikut: 


$$
\begin{gathered}
\mathrm{r}=\frac{\mathrm{n}\left(\sum x y\right)-\left[\left(\sum x\right)\left(\sum y\right)\right]}{\sqrt{\left\{n \sum X^{2}-\left(\sum X\right)^{2}\right\}}\left\{n \sum Y^{2}-\left(\sum Y\right)^{2}\right\}} \\
\mathrm{r}=\frac{5(1.152 .284)-(1.707)(3.393)}{\sqrt{\left\{5.616 .853-1.707^{2}\right\}}\left\{5.2 .358 .419-3.393^{2}\right\}} \\
\mathrm{r}=\frac{5.761 .420-5.791 .851}{\sqrt{\{3.084 .265-2.913 .849\}}\{11.792 .095-11.512 .449\}} \\
\mathrm{r}=\frac{-30,43}{\sqrt{47.656 .152 .453}\{279.646\}} \\
\mathrm{r}=\frac{-30,43}{218.302,89} \\
\mathrm{r}=-0,00014
\end{gathered}
$$

Dari hasil perhitungan dapat diketahui bahwa nilai $r=-0,00014$ dengan ketentuan nilai $r$ tidak lebih dan harga $(-1<r<+1)$. Apabila nilai $r=-1$ artinya korelasinya negatif sempurma; $r=0$ artinya tidak ada korelasi; dan $r=1$ berarti korelasinya sangat kuat. Dengan demikian dapat disimpulkan nilai $r=-$ 0,00014 artinya nilai koefisien korelasi tersebut mengacu pada hubungan yang sangat rendah dan bernilai negatif. Artinya jika variabel independen mengalami kenaikan maka menyebabkan variabel dependen menurun.

Selanjutnya menghitung Koefisien determinasi $(K d)$ untuk menghitung besarnya pengaruh biaya operasional terhadap laba perusahaan dengan rumus sebagai berikut:

$$
\begin{gathered}
K d=r^{2} \times 100 \% \\
K d=-0,00014^{2} \times 100 \% \\
K d=0,0000000196 \times 100 \% \\
K d=0,00000196 \%
\end{gathered}
$$

Dari hasil perhitungan diatas menghasilan koefisien determinasi sebesar $0,00000196 \%$. Dengan demikian maka besarnya pengaruh biaya operasional terhadap laba perusahaan adalah 0,00000196 \% sedangkan 99,99\% dipengaruhi oleh faktor lain yang tidak diteliti.

Untuk menguji hipotesis penelitian digunakan uji $t$

$$
\begin{gathered}
t=\frac{r \sqrt{n-2}}{\sqrt{1-r^{2}}} \\
t=\frac{-0,00014 \sqrt{5-2}}{\sqrt{1-(-0.00014)^{2}}} \\
t=\frac{-0.00014 \sqrt{3}}{\sqrt{1-0,0000000196}} \\
t=\frac{-0,00014.1,7320}{\sqrt{0,9999999804}} \\
t=\frac{-0,000242}{0,9999999902} \\
t=-0,000242
\end{gathered}
$$

Berdasarkan uji $t$ hitung sebesar $-0,000242$ aturan keputusan $\mathrm{dk}=(\mathrm{n}-2)=(5-2)=3$ pada taraf $\alpha=$ 0,05 (yang umum digunakan ) dengan $\mathrm{n}=5$ maka $t$ table adalah 3,182 dengan demikian maka harga $t$ hitung lebih kecil dari $t$ tabel, sehingga $\mathrm{Ho}$ diterima dan $\mathrm{Ha}$ ditolak. Jadi dari perhitungan-perhitungan diatas hipotesis yang diajukan ditolak, Hasil penelitian menunjukkan bahwa biaya operasioanal memiliki 
hubungan sangat rendah dan bernilai negatif. Biaya operasional tidak berpengaruh signifikan terhadap laba.

\section{Pembahasan}

1. Biaya Operasional Yang Dikeluarkan Media Group Electronic and Celluler Malangbong

Untuk mengetahui biaya operasional pada perusahaan Media Group Electronic and Celluler Malangbong dapat dilihat pada tabel 3.

Tabel 3. Biaya Operasional Periode Tahun 2016-2020

\begin{tabular}{ccc}
\hline Tahun & Biaya Operasional (X) (Rp) & \\
\hline 2016 & 279.600 .000 & 279,6 \\
2017 & 277.200 .000 & 277,2 \\
2018 & 485.000 .000 & 485 \\
2019 & 384.400 .000 & 384,4 \\
2020 & 280.800 .000 & 280,8 \\
Total & 1.707 .000 .000 & 1.707 \\
\hline
\end{tabular}

(Sumber Media Group Electronic and Celluler)

Berdasarkan data dari tabel 3 dapat diketahui biaya operasional yang dikeluarkan Media Group Electronic and Celluler dari tahun 2016 - 2020 mengalami kenaikan dan penurunan. Pada tahun 2016 biaya operasional sebesar Rp. 279.600.000 kemudian pada tahun 2017 biaya operasional yang dikeluarkan mengalami penurun sebesar 0,85 \% yaitu Rp. 2.400 .000 menjadi Rp. 277.200.000. Pada tahun 2018 mengalami kenaikan yang signifikan yakni sebesar 74,9\% yaitu sebesar Rp. 208.700.000 menjadi Rp. 485.000 .000 dikarenakan perusahaan membuat toko baru. Selanjutnya pada 2019 biaya operasional kembali turun menjadi Rp. 384.400 .000 namun masih dalam jumlah yang lumayan besar karena digunakan untuk finishing toko yakni sebasar Rp.100.600.000 atau turun 10,7\%, dan terakhir pada tahun 2020 biaya operasinal kembali mengalami penurunan sebesar $27 \%$ yakni sebesar Rp. 104.200.000 menjadi sebesar Rp. 280.800.000.

\section{Laba Yang Diperoleh Perusahaan Media Group Electronic and Celluler Malangbong.}

Untuk mengetahui besarnya laba yang diperoleh oleh Media Group Electronic and Celluler disajikan dalam tabel laba rugi dibawah ini

Tabel 4. Laba Bersih Usaha Periode Tahun 2016-2020

\begin{tabular}{ccc}
\hline Tahun & Laba Bersih Usaha $(X)(\mathrm{Rp})$ & \\
\hline 2016 & 680.400 .00 & 279,6 \\
2017 & 706.800 .000 & 277,2 \\
2018 & 663.000 .00 & 485 \\
2019 & 651.600 .000 & 384,4 \\
2020 & 691.200 .000 & 288,8 \\
Total & 3.393 .000 .000 & 3.393 \\
\hline
\end{tabular}

(Sumber Media Group Electronic and Celluler)

Berdasarkan tabel 1 laba yang diperoleh Media Group Electronic and Celluler Malangbong pada tahun 2016 sebesar Rp.680.400.000. Kemudian pada tahun 2017 laba yang diperoleh mengalami peningkatan sebesar 3,9 \% yaitu sebesar Rp.26.400.000 menjadi Rp. 706.800.000. Kemudian pada tahun 2018 kembali mengalami penurunan menjadi (6,2\%) salah satunya karena adanya pembangunantoko baru sehingga laba yangdiperoleh sebesar Rp.663.000.000. Selanjutnya pada tahun 2019 kembali mengalami penurunan sebesar $(1,7 \%)$ adanya tambahan biaya operasional yang digunakan untuk finishing toko sehingga laba yang diterima yakni sebesar Rp.11.400.000 untuk tahun 2020 laba yang diperoleh mengalami kenaikan sebesar 6,1 \% yaitu sebesar Rp. 39.600.000. 


\section{Pengaruh Biaya Operasional Terhadap Laba Perusahaan}

Berdasarkan perhitungan koefisien determinasi dapat disimpulkan bahwa pengaruh biaya operasional terhadap laba perusahaan adalah sebesar 0, $0000000196 \%$, sedangkan sisanya sebesar $99,99 \%$ dipengaruhi oleh faktor lain yang tidak diteliti penulis. Berdasarkan perhitungan uji hipotesis dengan menggunakan uji t dihasilkan nilai $t_{\text {hitung }}=-0,00242$ aturan keputusan $\mathrm{dk}=(\mathrm{n}-2)=(5-2)=3$ pada taraf $\alpha=0,05$ (yang umum digunakan ) dengan $n=5$ maka $t$ table adalah 3,182 dengan demikian maka harga $t$ hitung lebih kecil dari $t$ tabel, sehingga $\mathrm{Ho}$ diterima dan $\mathrm{Ha}$ ditolak. Jadi dari perhitunganperhitungan diatas hipotesis yang diajukan ditolak, yaitu biaya operasional tidak berpengaruh secara signifikan terhadap laba perusahaan. Besar kecilnya biaya operasional tidak mempengaruhi kemampuan perusahaan dalam menghasilkan laba perusahaan, karena biaya operasional terbagi menjadi beberapa biaya sehingga jika diteliti biaya operasional saja terlalu luas dan tidak spesifik sehingga menghasilkan korelasi yang sangat rendah dan bernilai negatif yang artinya biaya operasional tidak berpengaruh signifikan terhadap laba.

\section{KESIMPULAN}

Penelitian ini dilakukan untuk mengetahui seberapa besar pengaruh Biaya Operasional terhadap Laba Perusahaan. Berdasarkan analisis hasil penelitian yang telah dilakukan, maka dapat di simpulkan bahwa:

1. Biaya operasional yang dikeluarkan Media Group Elekcronic and Celluler dari tahun 2016 - 2020 mengalami kenaikan dan penurunan (fluktuatif).

2. Laba yang diperoleh oleh Media Group Electronic and Celluler Malangbong mengalami kenaikan dan penurunan (fluktuatif).

3. Biaya operasional tidak berpengaruh signifikan yakni sebesar $0,00000196 \%$ terhadap laba perusahaan.

\section{REKOMENDASI}

Berdasarkan kesimpulan diatas, maka peneliti menyampaikan saran-saran sebagai berikut:

1. Penggunaan biaya operasional diperusahaan sudah baik namun harus tetap dievaluasi.

2. Manajemen perusahaan dalam menggunakan laba untuk memperbesar bisnis sangat baik sehingga perusahaan sudah memiliki beberapa cabang seperti saat ini.

3. Untuk peneliti selanjutnya sebaiknya penggunaan biaya operasional sebagai variabel lebih dirinci guna memudahkan penelitian dan tergantung jenis perusahaan yang diteliti

\section{UCAPAN TERIMAKASIH}

Terimakasih yang sebesar-besarnya kepada Universitas Galuh Ciamis terutama kepada seluruh staff, dosen, serta rekan-rekan mahasiswa FKIP Prodi Akuntansi yang telah membantu kelancaran pembuatan jurnal ini meskipun masih jauh dari kata sempurna penulis berharap dapat memberikan manfaat dan menambah wawasan.

\section{DAFTAR PUSTAKA}

Halim, A., Supomo, B., \& Kusufi, M. S. (2012). Akuntansi Manajemen (Akuntansi Manajerial). Edisi . Yogyakarta: BPFE.

Jumingan. (2017). Analisis Laporan Keuangan. Jakarta: PT. Bumi Aksara.

Mulyadi. (2013). Sistem Akuntansi, Edisi Ketiga, Cetakan Keempat. Jakarta : Salemba Empat.

Subramanyam, K. R. (2014). Analisis Laporan Keuangan. Diterjemahkan oleh Febriela Sirait dan Teguh Iman Maulana. Edisi kesebelas. Jakarta: Salemba Empat 
Sujarweni, V. W. (2015). Akuntansi Biaya. Yogyakarta : Bary Press. 